\title{
Foreign Labour on Malaysian Growth
}

\author{
Rahmah Ismail \\ Universiti Kebangsaan Malaysia, Selangor, Malaysia
}

Ferayuliani Yuliyusman

Universiti Kebangsaan Malaysia, Selangor, Malaysia

\begin{abstract}
This paper is to examine the impact of foreign labour on Malaysian economic growth using panel data from three sectors: manufacturing, services, and construction for the period of 1990 2010. The short run and long run effects of foreign labour on output growth are analysed using the Autoregressive Distributed Lag approach. The study shows that the skilled and semi-skilled foreign labours have a positive and significant impact on the output growth in both the short run and the long run. However, the study finds that the unskilled foreign labour adversely affects output growth in both the short run and the long run.
\end{abstract}

JEL Classifications: J01, J08

Keywords: Skilled Foreign Labour, Semi-skilled Foreign Labour, Unskilled Foreign Labour, Economic Growth

\footnotetext{
* Corresponding Author: Rahmah Ismail; School of Economics Faculty of Economics and Management, Universiti Kebangsaan Malaysia, Bangi Selangor 43600, Malaysia; E-mail: rahis@ukm.edu.my.

Co-Author: Ferayuliani Yuliyusman; School of Economics Faculty of Economics and Management, Universiti Kebangsaan Malaysia, Bangi Selangor 43600, Malaysia.
}

Acknowledgement: The authors would like to thank the University Kebangsaan Malaysia for providing a grant to conduct this study. 


\section{Introduction}

Macroeconomists and international trade economists have examined the influence of migration on economic growth, which may be particularly interesting in the context of increasing returns to scale. Rachel and Jeniffer (1995) argue that recent theoretical work has made strides toward explaining the possible links between immigration and growth. Theoretically, the recruitment of migrant workers could have a number of negative effects, including: (i) a reduction in employment rates as employers use migrants to replace native workers (displacement effect); (ii) an increase in the unemployment rate; (iii) reduction in vacancies; and (iv) the suppression of wage levels. According to Green et al. (2007), two main reasons exist concerning why employers recruit migrant workers: (i) to perform jobs that require specialist skills which are not available in the host country (i.e., to address skill shortages and deficiencies); and (ii) to fill in the vacancies for which there are insufficient number of domestic workers.

Portes and French (2005) suggest that the effect of foreign labour is traditionally viewed in terms of complementarity or substitutability with natives in the provision of household services. A review of literature shows that results concerning the impact of foreign labour on a host economy have been giving mixed signals. On the one hand, foreign labour helps to address labour market deficiencies, supplying labour to fill vacancies where there are insufficient number of workers and skill shortages in certain economic sectors. The influx of foreign labour subsequently helps the host economy to sustain positive growth by allowing for a continuous increase in productivity and output. On the other hand, findings also show that foreign labour could have a number of negative effects. Athukorala (1992) states that the evidence indicates migrant labours are sending their income back to their home country in the form of remittance outflow, which affects the balance of payment of the host country.

Malaysia relies heavily on foreign labour, particularly in low-end economic activities like in the agriculture and business informal sectors. The employment of foreign labour is predominant in the construction, plantations and the low-end services sector such as gas station attendants, security guards, and housemaids. In 2010, the number of registered foreign labours in Malaysia reached approximately 2.0 million, which is approximately $17.0 \%$ of total employment. The figure is likely to double if the illegally employed foreign labours in Malaysia are included (Ministry of Home Affairs 2011). Foreign labours consist of professionals, skilled, and unskilled labours and 
mainly concentrated in the manufacturing, construction, and agriculture sectors (Central Bank of Malaysia 2011). Kanapathy (2008) indicates that unskilled and semi-skilled labours constitute the largest component of migrants in Malaysia. As of 2006, 1,869,209 unskilled and semi-skilled foreign labours were present in Malaysia from 23 countries. The number of expatriates, professional, and technical migrants was 55,549 during the same year.

An extensive use of semi-skilled and unskilled foreign labour will inhibit the use of new technologies within firms since it is much cheaper to engage in labour intensive tasks using older technology. Nonetheless, in certain sectors, mainly construction, plantation and low-end services sectors, foreign labour is crucial since not many local labours are opt to work in these sectors. Therefore, foreign labour is required to sustain these sectors. However, the presence of foreign labours are also likely to bring other negative effects to the host economy as demonstrated in extant studies.

According to the Central Bank of Malaysia Annual Report 2013 (Central Bank 2013), the conservative projection of Malaysia economic growth is $4.5 \%$ to $5.5 \%$ for 2014 rather than what was projected earlier by the Malaysian federal government of $5 \%$ to $5.5 \%$. The conservative growth outlook was lower due to perceived risks from the global economy and other external factors, such as the heavy reliance on foreign workers. Economic sectors involving the extensive use of foreign labour, including the agricultural, mining and construction sectors, will have lower growth due to the unskilled and less productive foreign workers.

Although several studies attempt to examine issues relating to foreign labour in Malaysia, no serious effort has been made to assess the impact of foreign labour on Malaysian economic growth. The present study examines the issue using a more comprehensive approach involving the employment of Autoregressive Distributed Lag (ARDL), through which the long run and short run effects will be demonstrated. The study is important to provide a better understanding on the impact of foreign labour on the host economy.

The paper is organised as follows. The next section presents a literature review of empirical findings from previous studies. This is followed by sections presenting the methodology, results, and the conclusions. 


\section{Trend of Migration in Malaysia}

Table 1 presents the number of migrant workers in Malaysia by country of origin and shows that Indonesia comprises the highest number of migrants for all of the years, followed by Bangladesh, Pakistan, Thailand, and the Philippines. The number of Indonesian migrants to Malaysia increased considerably from 269,194 in 1999 to approximately 1.2 million in 2006 and slightly dropped to 1.1 million in 2008 . They make up more than half of the total number of migrants in Malaysia. Migration from the Philippines showed an increasing trend over time for which the number was between 7,299 and 26,713 from 1990 to 2008. The number of migrants from Thailand showed an unstable trend, from only 2,130 in 1999 to 20,599 in 2002, 5,751 in 2005 and then increased to 21,065 in 2008. Although the percentage of the Philippine and Thai migrants is quite low, making up less than $5 \%$, its impact is rather significantly on the Malaysian economy. Considering their close proximity to Malaysia, future international mobility from these three countries into Malaysia is anticipated to increase.

Table 1. Number of migrant workers in Malaysia by country of origin

(Measurement unit: \%)

\begin{tabular}{|c|c|c|c|c|}
\hline \multirow{2}{*}{ Country of Origin } & \multicolumn{4}{|c|}{ Year } \\
\hline & 1999 & 2002 & 2005 & 2008 \\
\hline Indonesia & $\begin{array}{c}269,194 \\
(65.7)\end{array}$ & $\begin{array}{c}788,221 \\
(73.8)\end{array}$ & $\begin{array}{c}1,211,584 \\
(66.7)\end{array}$ & $\begin{array}{c}1,085,658 \\
(52.6)\end{array}$ \\
\hline Bangladesh & $\begin{array}{c}110,788 \\
(27.0)\end{array}$ & $\begin{array}{c}82,642 \\
(7.7)\end{array}$ & $\begin{array}{c}55,364 \\
(3.0)\end{array}$ & $\begin{array}{c}316,401 \\
(15.3)\end{array}$ \\
\hline Thailand & $\begin{array}{c}2,130 \\
(0.5)\end{array}$ & $\begin{array}{c}20,599 \\
(1.9)\end{array}$ & $\begin{array}{l}5,751 \\
(0.3)\end{array}$ & $\begin{array}{c}21,065 \\
(1.0)\end{array}$ \\
\hline Philippines & $\begin{array}{c}7,299 \\
(1.8)\end{array}$ & $\begin{array}{c}21,234 \\
(2.0)\end{array}$ & $\begin{array}{c}21,735 \\
(1.2)\end{array}$ & $\begin{array}{c}26,713 \\
(1.3)\end{array}$ \\
\hline Pakistan & $\begin{array}{c}2,605 \\
(0.6)\end{array}$ & $\begin{array}{c}2,000 \\
(0.2)\end{array}$ & $\begin{array}{c}13,297 \\
(0.7)\end{array}$ & $\begin{array}{c}21,278 \\
(1.0)\end{array}$ \\
\hline Others & $\begin{array}{c}17,644 \\
(4.3)\end{array}$ & $\begin{array}{c}152,833 \\
(14.3)\end{array}$ & $\begin{array}{c}507,507 \\
(28.0 \mathrm{~s})\end{array}$ & $\begin{array}{c}591,481 \\
(28.7)\end{array}$ \\
\hline Total & $\begin{array}{c}409,660 \\
(100.0)\end{array}$ & $\begin{array}{c}1,067,529 \\
(100.0)\end{array}$ & $\begin{array}{c}1,815,238 \\
(100.0)\end{array}$ & $\begin{array}{c}2,062,596 \\
(100.0)\end{array}$ \\
\hline
\end{tabular}

(Source) Ministry of Home Affairs, Malaysia, 2008. 
The majority of the migrant workers are in the manufacturing sector, comprising with more than $30 \%$ of the total migrants in Malaysia. The second largest number of foreign workers are concentrated in the plantation sector. The foreign workers in the construction sector are the fourth largest as shown in Table 2.

Table 2. Number of migrant workers in Malaysia by sector

(Measurement unit: \%)

\begin{tabular}{|c|c|c|c|c|c|}
\hline \multirow{2}{*}{ Sector } & \multicolumn{5}{|c|}{ Year } \\
\hline & 1999 & 2002 & 2005 & 2008 & 2011 \\
\hline Maid & $\begin{array}{c}94,192 \\
(23.0)\end{array}$ & $\begin{array}{c}232,282 \\
(22.0)\end{array}$ & $\begin{array}{c}320,171 \\
(17.6)\end{array}$ & $\begin{array}{c}293,359 \\
(14.2)\end{array}$ & $\begin{array}{c}184,092 \\
(11.7)\end{array}$ \\
\hline Manufacturing & $\begin{array}{c}155,277 \\
(37.9)\end{array}$ & $\begin{array}{c}323,299 \\
(30.6)\end{array}$ & $\begin{array}{c}581,379 \\
(32.0)\end{array}$ & $\begin{array}{c}728,867 \\
(35.3)\end{array}$ & $\begin{array}{c}580,820 \\
(36.9)\end{array}$ \\
\hline Plantation & $\begin{array}{l}74,501 \\
(18.2)\end{array}$ & $\begin{array}{c}298,325 \\
(28.2)\end{array}$ & $\begin{array}{c}472,246 \\
(26.0)\end{array}$ & $\begin{array}{c}333,900 \\
(16.2)\end{array}$ & $\begin{array}{c}299,217 \\
(19)\end{array}$ \\
\hline Construction & $\begin{array}{c}49,080 \\
(12.0)\end{array}$ & $\begin{array}{c}149,342 \\
(14.1)\end{array}$ & $\begin{array}{c}281,780 \\
(15.5)\end{array}$ & $\begin{array}{c}306,873 \\
(14.9)\end{array}$ & $\begin{array}{c}223,688 \\
(14.2)\end{array}$ \\
\hline Services & $\begin{array}{c}36,610 \\
(8.9)\end{array}$ & $\begin{array}{c}64,281 \\
(6.1)\end{array}$ & $\begin{array}{c}159,662 \\
(8.8)\end{array}$ & $\begin{array}{c}211,630 \\
(10.3)\end{array}$ & $\begin{array}{c}132,919 \\
(8.4)\end{array}$ \\
\hline Agriculture & na & na & na & $\begin{array}{c}186,967 \\
(9.1)\end{array}$ & $\begin{array}{c}152,325 \\
(9.6)\end{array}$ \\
\hline Total & $\begin{array}{c}409,660 \\
(100.0)\end{array}$ & $\begin{array}{c}1,067,529 \\
(100.0)\end{array}$ & $\begin{array}{c}1,815,238 \\
(100.0)\end{array}$ & $\begin{array}{c}2,062,596 \\
(100.0)\end{array}$ & $\begin{array}{c}1,5730,61 \\
(100.0)\end{array}$ \\
\hline
\end{tabular}

(Note) na is not available.

(Source) Ministry of Home Affairs, Malaysia, 2008, 2011.

\section{Literature Review}

Evidence appears to suggest that migrants tend to go where labour demand is buoyant, filling gaps in the labour market and subsequently contributing to the output of the economy. Studies also tend to suggest that migration process is beneficial to the economy in addressing labour shortages and skill deficiencies thereby have a 
positive effect on output. For example, Portes and French (2005) find that the primary impact of Eastern European migration to the United Kingdom since its accession to EU is an increase in output. Green et al. (2007) find that migrant workers make an important contribution to the West Midlands economy in the UK, contributing to 5\% of the regional output. Zimmermann (1995) claims that immigration creates extra demand for goods and services; thus positively affecting output growth. However, the study by Friedberg and Hunt (1995), which uses a modified Solow growth model, determines that the effects of migration on the economic growth of the host country are insignificant.

In a study by Coury and Lahouel (2011), the supply of foreign labour is assumed to be perfectly elastic. The presence of foreign labour in Gulf Cooperation Council (GCC) countries results in a stagnant growth rate of the per capita income because the majority of the labours are unskilled. Tangavelu (2012) examines the role of foreign labour in Singapore and found that foreign labours have a positive effect on economic growth and the effect depends on the types of economic activities in which foreign labours are utilized. Greater benefits are gained in more innovative sectors, including Information and Communication Technology (ICT) and the tourism industry. The positive effect of foreign labour on the economic growth of Singapore can be associated with the level of skills possessed by foreign labours. The majority of foreign labours that enter Singapore are skilled labours because the presence of strict regulations regarding foreign labour makes it difficult for unskilled labourers to enter Singapore.

Christofides et al. (2007) study foreign labour in Cyprus using time series data from the period of 1996 until 2006. According to this study, Cyprus experienced tremendous economic growth during that period, which subsequently resulted in a labour shortage. The country was required to rely upon foreign labour to sustain its economic activities. The study suggests that the positive effect from employing foreign labour depends on the education level and skills of the foreign labours. Highly educated and skilled foreign labours have a positive impact on the economic growth in Cyprus, whereas less educated and unskilled foreign labours have a negative impact.

Drinkwater et al. (2007) revisits Borjas' work (1995) by calibrating a three-sector general equilibrium model with endogenous growth to European Union economiesm, and redefined immigration surplus in terms of the increase in welfare levels among the natives in the post-immigration era. The study concludes that unskilled immigrants have a negative impact on the size of immigration surplus and support the immigration policies that favour skilled immigrants. By comparing their results with that of Borjas 
(1995), Drinkwater et al. (2007) conclude that the positive effect of skilled immigrants is larger in the dynamic case than that of the Borjas' static case. Skilled immigrants tend to increase long-term growth by stimulating more skill-intensive R\&D activities in the innovative sector. The gains in growth and immigration surplus increase further when complementarity exists between skilled workers and physical capital.

In Malaysia, several attempts have been made to examine issues relating to foreign labour, including the studies by Azizah (1998a, 1998b), Zehadul et al. (1999), Pillai (1998), Kurus (1998), Solehah and Dicks (1999), and Rahmah et al. (2003). Azizah (1998a; 1998b) provides a comprehensive review of the history and existing roles of foreign labour in Malaysia. Both studies also outline governmental acts and regulations relating to migrant workers, while highlighting problems concerning data compilation for research on the migrant workers. Azizah (1998b) proposes that the Malaysian government should implement a more transparent and comprehensive policy to govern migrant workers.

In another study, Pillai (1998) analyses the effect of the 1997 Asian economic crisis on the migrant labour in Malaysia. The study hypothesises that the economic crisis would further accelerate the inflows of foreign labour into the country, especially the illegal migrant workers. The study also predicts that the crisis would likely reduce the income and work conditions of foreign labours engaged in low-end activities that were badly affected by the crisis, including construction, manufacturing, and services. The study recommends that Malaysia formulate a more comprehensive policy concerning migrant labour in the future. Similar to Pillai, Kurus (1998) also examines the impact of the 1997 Asian economic crisis on migrant labour, but the study focuses on Sabah, where migrant labour makes up a large portion of the population. Similar to previous studies, Kurus (1998) also suggests that the Malaysian government should implement a more systematic mechanism to monitor and facilitate the movement of foreign labours within the region, which could be accomplished through a multilateral agreement with the sending countries.

Solehah and Dicks (1999) find that Malaysian firms continue to demand migrant workers because it is cost-effective. According to the study, most employers believe it is much cheaper to employ foreign labour due to relatively low wages than investing in expensive high technology machinery. For many employers, the main advantage of hiring migrant workers is that they are perceived as having a more positive work attitude and ethic than native workers. Green et al. (2007) claims that it is an attitude gap rather than a skill gap that results in employers' tendency to recruit migrants. 
Rahmah et al. (2003) study the impact of foreign labour on output growth and the demand for foreign labour in the Malaysian manufacturing sector. The study finds that professional foreign labour contributes significantly to manufacturing output growth. In addition, the study finds that professional foreign labour and local labour are complementory, while the unskilled foreign labour and local labour are substitutes.

\section{Methodology and Model Specification}

This section is divided into three subsections to include the discussion on dynamic panel data analysis, model specification, and the source of data. The analysis in this paper uses Autoregressive Distributed Lag (ARDL) method, which was introduced by Pesaran et al. (1999). This method is well suited for the analysis of dynamic panel data that have both large time series and cross-sectional data.

\section{A. Dynamic panel data analysis}

Pesaran et al. (1999) introduced a dynamic panel data analysis using the ARDL approach, which involves the estimation of Pooled Mean Group (PMG) or Mean Group (MG) that will capture the long run and short run relationships between the variables of interest. Therefore, the estimation of PMG and MG will be conducted in this study and based on the results of the Hausman test, one model will be chosen for the analysis. If the Hausman test is not statistically significant, the PMG model will be chosen since it produces a more efficient result. In general, the model for panel analysis of the unrestricted error correction ARDL is written as follows (Pesaran et al. 1999):

$$
\begin{aligned}
& \Delta y_{i t}=\phi_{i}\left(y_{i, t-1}-\beta_{i}^{\prime} x_{i, t-1}\right)+\sum_{j=1}^{p-1} \lambda_{i j} \Delta y_{i, t-j}+\sum_{j=0}^{q-1} \gamma_{i j}^{\prime} \Delta x_{i, t-j}+\mu_{i}+u_{i t} \\
& i=1,2, \ldots ; t=1,2, \ldots T
\end{aligned}
$$

where $y_{i t}$ is a scalar dependent variable; $x_{i t}$ is the $k \mathrm{x} 1$ vector of regressors for group $i$; $\phi_{i}$ is a scalar coefficient of the lagged dependent variable; $\beta_{i}^{\prime}$ is the $k \times 1$ vector of 
coefficients of explanatory variables; $\lambda_{i j}$ represents the scalar coefficients of lagged first-differences of dependent variables; $\gamma^{\prime}{ }_{i j}$ are $k \times 1$ coefficient vectors of the firstdifference of explanatory variables and their lagged values; and $\mu_{i}$ represents the fixed effects. The disturbances $\left(\mu_{i}\right)$ are assumed to be independently distributed across $i$ and $t$ with mean equal to zero and variance greater than zero; $\delta^{2}>0$. Furthermore, the error correction term is assumed to be less than zero $\left(\phi_{i}<0\right)$ for all $i$ in which a long run relationship exists between $y_{i t}$ and $x_{i t}$;

$$
\begin{gathered}
y_{i t}=\theta_{i}^{\prime} x_{i t}+\eta_{i t} \\
i=1,2, \ldots N ; t=1,2, \ldots T
\end{gathered}
$$

where $\theta_{i j}^{\prime}=-\frac{\beta_{t}^{\prime}}{\phi_{i}}$ is the $k \times 1$ vector of the long run coefficients; and $\eta_{i t}$,'s stationary with possibly non-zero means including fixed effects.

Equation (2) can be rewritten as a VECM system as follows:

$$
\Delta y_{i t}=\phi_{i} \eta_{i, t-1}+\sum_{j=1}^{p-1} \lambda_{i j} \Delta y_{i, t-j}+\sum_{j=0}^{q-1} \gamma_{i j}^{\prime} \Delta x_{i, t-j}+\mu_{i}+u_{i t}
$$

where $\eta_{i, t-1}$ is the error correction term and, hence, $\phi_{i}$ is the error correction coefficient measuring the speed of adjustment towards the long-run equilibrium. Pesaran et al. (1999) states that in order to determine the long run relationship between the variables, an Error Correction Term (ECT) or hypothesis $\varphi_{i}<0$ is required. Due to the greater number of time series $(t)$ compared to number of cross sections $(n)$, the PMG or MG estimation is more appropriate than the General Method Moment (GMM) (Pesaran 1999). The analysis employs dynamic panel data concerning three sectors: the manufacturing, construction, and agricultural sectors.

\section{B. Model specification}

The present study uses an economic growth model based upon the Cobb-Douglas production function, which take the following form:

$$
Y_{t}=A K_{t}^{\beta 1} L L_{t}^{\beta 2} L F_{t}^{\beta 3} e^{\mu t}
$$


where $Y$ is total output; $K$ is value of capital stock; $L L$ is quantity of local labour; $L F$ is quantity of foreign labour; $\beta_{1} \ldots \beta_{3}$ are parameters; and $t$ is time. When the variables are measured in relation to growth, Equation (1) can be written as:

$$
g_{Y y}=\beta_{0}+\beta_{1} g_{K}+\beta_{2} g_{L}+\beta_{3} g_{E}+\mu_{t}
$$

Alongside basic production inputs such as capital and labour, output growth is also determined by other variables, including Foreign Direct Investment (FDI), economic openness, and Research and Development (R\&D). In order to examine the impact of foreign labour on Malaysian economic growth, the study estimates two models. The first model uses general data concerning local and foreign labours, while the second model uses data concerning local and foreign labour according to their job categories. The ARDL estimations models are written as follows:

Model 1

$$
\begin{aligned}
& \Delta g O U P_{i t}=\alpha_{0}+\phi_{i} g O U P_{i, t-1}+\beta_{1} g F D I_{i, t-1}+\beta_{21} g O P N_{i, t-1}+\beta_{31} g R \& D_{i, t-1}+\beta_{41} g K_{i, t-1} \\
& +\beta_{51} g T L L_{i, t-1}+\beta_{61} g T L F_{i, t-1}+\sum_{j=1}^{p-1} \lambda_{1 j} \Delta g O U P_{i, t-j}+\sum_{j=0}^{q-1} \gamma_{1 j} \Delta g F D I_{i, t-j}+\sum_{j=0}^{p-1} \gamma_{21 j} \Delta g O P N_{i, t-j} \\
& +\sum_{j=0}^{p-1} \gamma_{31 j} \Delta g R \& D_{i, t-j}+\sum_{j=0}^{p-1} \gamma_{41 j} \Delta g K_{i, t-j}+\sum_{j=0}^{p-1} \gamma_{51 j} \Delta T L L_{i, t-j}+\sum_{j=0}^{p-1} \gamma_{61 j} \Delta g T L F_{i, t-j}+\varepsilon_{1 t}
\end{aligned}
$$

Model 2

$$
\begin{aligned}
& \Delta g O U P_{i t}=\alpha_{1}+\phi_{2} g O U P_{i, t-1}+\beta_{12} g F D I_{i, t-1}+\beta_{2} g O P N_{i, t-1}+\beta_{32} g R \& D_{i, t-1}+\beta_{42} g K_{i, t-1} \\
& +\beta_{52} g S L L_{i, t-1}+\beta_{62} g S F L_{i, t-1}+\beta_{72} g S S L L_{i, t-}+\beta_{82} g S S F L_{i, t-1}+\beta_{92} g U S L L_{i, t-1}+\beta_{102} g U S F L_{i, t-1} \\
& +\sum_{j=1}^{p-1} \lambda_{2 j} \Delta g O U P_{i, t-j}+\sum_{j=0}^{p-1} \gamma_{12 j} \Delta g F D I_{i, t-j}+\sum_{j=0}^{p-1} \gamma_{22 j} g O P N_{i, t-j}+\sum_{j=0}^{p-1} \gamma_{32 j} \Delta g R \& D_{i, t-j}+\sum_{j=0}^{p-1} \gamma_{42 j} \Delta g K_{i, t-j} \\
& +\sum_{j=0}^{p-1} \gamma_{52 j} \Delta g S L L_{i, t-j}+\sum_{j=0}^{p-1} \gamma_{62 j} \Delta g S F L_{i, t-j}+\sum_{j=0}^{p-1} \gamma_{72 j} \Delta g S S L_{i, t-j}+\sum_{j=0}^{p-1} \gamma_{82 j} \Delta g S S F L_{i, t-j}+\sum_{j=0}^{p-1} \gamma_{92 j} \Delta g U S L L_{i, t-j} \\
& +\sum_{j=0}^{p-1} \gamma_{102 j} \Delta g U S F L_{i, t-j}+\varepsilon_{2 t}
\end{aligned}
$$


where, gOUPT is the growth of real sectoral output; FDI is the growth of Malaysian real FDI, $g O P N$ is the growth of real economic openness in Malaysia, which is calculated as the real export and import value divided by the real Gross Domestic Product (GDP); $g R \& D$ is the growth of real expenditure on research and development; $g K$ is the growth of real capital value; $g T L L$ is the growth of total local labour; $g T L F$ is the growth of total foreign labour; $g S L L$ is the growth of skilled local labour; $g S F L$ is the growth of skilled foreign labour; $g S S L L$ is the growth of semi-skilled local labour; gSSFL is the growth of semi-skilled foreign labour; $g U S L L$ is the growth of unskilled local labour; $g U S F L$ is the growth of unskilled foreign labour; $i$ is sector, which consists of three main sectors, $t$ is year; $\alpha_{1}, \alpha_{2,} \lambda_{1 j}, \lambda_{2 j}, \beta_{11 \ldots . . .} \beta_{102,,} \delta_{11 j} \cdots V_{102 j}$ are parameters; and $\varepsilon_{1 t}, \varepsilon_{2 t}$ are the error terms.

\section{Source of data}

Since the study involves dynamic panel data analysis, sectoral data is utilised. The study covers three main economic sectors where the hiring of foreign labour is more prevalent: the manufacturing, services, and construction sectors. These three sectors are also the main contributors to the growth of the Malaysian economy, contributing more than three quarters of the GDP. The data is gathered from three industrial surveys: the Industrial Manufacturing Survey, the Industrial Services Survey, and the Industrial Construction Survey of 1990 2010. The survey data provide three main variables for the study, which are output, number of local labour, and number of foreign labour. Alongside these variables, the present study incorporates other variables, including FDI, economic openness, and R\&D. Data concerning FDI is gathered from the Ministry of International Trade and Industry (MITI). Data concerning exports, imports and GDP, which are utilised to measure economic openness, are gathered from the Ministry of Finance (MOF). Finally, data concerning R\&D is gathered from the Ministry of Science, Technology and Innovation (MOSTI). All data values are in real terms and based upon the year 2000 . 


\section{The Results}

Based upon the Hausman test, the Hausman Probability of chi-square in Model 1 is 0.9997 and for Model 2 is 0.8651 , which are not significant at the $10 \%$ significance level. Thus, PMG estimations are selected for both models since their estimators are more efficient.

The results of the PMG estimation are shown in Tables 3 and 4. Table 3 presents the results of PMG estimation using $\operatorname{ADRL}(0,1,1,0,1,1,1)$. For this model, the results in the long run demonstrate that all coefficients are positive and statistically significant at $1 \%$, influencing the growth of overall sectoral output ( $g O U P T) .1 \%$ point increase in the number of foreign labour will increase the sectoral output growth by 0.004 percentage point. However, the effect of local labour on the output growth is higher than that of the foreign labour at 0.018 percentage point. Other variables that positively affect the long run output growth are FDI, OPN, R\&D, and K. Meanwhile, the growth of OPN, K, TLL are positive and statistically significant only in the short run at the $1 \%$ significance level. The results imply that foreign labours must be allowed to work for longer periods in order for the Malaysian economy to benefit from their presence. The long run positive effect may be due to better adaptation to local technology among the foreign labours. 
Table 3. Pooled mean group regression model 1

Dependent Variable: Output Growth

(ARDL 0,1,1,0,1,1,1)

\begin{tabular}{|c|c|c|c|}
\hline Independent Variables & The long run results & $\chi^{2}(2)$ & P-value \\
\hline \multicolumn{4}{|l|}{$g G D P_{t-1}$} \\
\hline$g F D I_{t-1}$ & $0.0003(4.41)^{* * *}$ & & \\
\hline$g O P N_{t-1}$ & $0.0057(2.60) * * *$ & & \\
\hline$g R \& D_{t-1}$ & $0.0220(3.21)^{* * *}$ & & \\
\hline$g K_{t-1}$ & $0.0037(2.76)^{* * *}$ & & \\
\hline$g T L L_{t-1}$ & $0.0180(2.47)^{* * *}$ & & \\
\hline \multirow[t]{2}{*}{$g T L F_{t-1}$} & $0.0040(2.66) * * *$ & & \\
\hline & The short run results & & \\
\hline \multicolumn{4}{|l|}{$\Delta g G D P_{t}$} \\
\hline$E C T$ & $-0.7133(6.80)^{* * *}$ & & \\
\hline$\Delta g F D I_{t-1}$ & $0.0027(0.01)$ & & \\
\hline$\triangle g O P N_{t-1}$ & $0.2277(2.51)^{* * *}$ & & \\
\hline$\Delta g R \& D_{t}$ & $0.0022(0.46)$ & & \\
\hline$\Delta g K_{t-1}$ & $0.0018(3.71)^{* * *}$ & & \\
\hline$\Delta g T L L_{t-1}$ & $0.0024(1.95) * * *$ & & \\
\hline$\Delta g T L F_{t-1}$ & $0.0038(1.11)$ & & \\
\hline Constant & $0.7110(7.56)^{* * *}$ & & \\
\hline Hausman Test & & 2.4 & 0.9997 \\
\hline
\end{tabular}

(Notes) (i) Number in the parenthesis represents the absolute value for $z$.

(ii) $* * *$ denote statistical significance at the $1 \%$ level,

** denote statistical significance at the $5 \%$ level,

$*$ denote statistical significance at the $10 \%$ level. 
PMG estimation results for the second model are shown in Table 4. The results for the long run demonstrate that some of the variables are positive and statistically significant, but some of them are significantly negative. The growth of both skilled and semi-skilled local labour and foreign labour have a positive and statistically significant effect on the growth of sectoral output. 1\% point increase in the skilled and semiskilled foreign labour will increase output growth by 0.0090 and 0.0561 percentage points, respectively. Meanwhile, the coefficients of the unskilled local labour and foreign labour are negative and significantly affect the sectoral output growth at the $1 \%$ significance level. Based on the results, $1 \%$ point increase in the growth of unskilled local labour will decrease output growth by 0.0241 percentage points, and $1 \%$ point increase in unskilled foreign labour will reduce output growth by 0.0450 percentage point. Therefore, it is proven that skilled foreign labours benefit Malaysian economic growth in the three sectors examined. Other variables that positively affect sectoral output growth in the long run include FDI, OPN, R\&D, and $\mathrm{K}$.

Meanwhile, the results show that only the growth of the FDI, OPN, R\&D, K, and USLL variables have a positive and statistically significant effect on the gGDP in the short run, but the growth of the unskilled foreign labour demonstrates a significant and negative effect. Therefore, the use of unskilled foreign labour jeopardises Malaysian economic growth in both the long run and the short run. Skilled and semi-skilled foreign labours, even though not statistically significant in the short run, are highly significant in the long run. This implies that the positive contribution of skilled and unskilled foreign labour to sectoral output growth will be observed in the long run when the adaptation of such labour to new technology can more easily take place.

The results again suggest that the economy must utilise skilled foreign labour in the long run in order to obtain benefits in the form of higher output growth. 
Table 4. Pooled mean group regression model 2

Dependent Variable: Output Growth

(ARDL 0,0,0,0,1,1,0,0,1,1,0)

\begin{tabular}{|c|c|c|c|}
\hline $\begin{array}{l}\text { Independent } \\
\text { Variables }\end{array}$ & The long run coefficients & $\chi^{2}(2)$ & P-value \\
\hline \multicolumn{4}{|l|}{$g G D P_{t-1}$} \\
\hline$g F D I_{t-1}$ & $0.0036(2.16)^{* *}$ & & \\
\hline$g O P N_{t-1}$ & $0.8610(6.72) * * *$ & & \\
\hline$g R \& D_{t-1}$ & $0.0025(7.21)^{* * *}$ & & \\
\hline$g K_{t-1}$ & $0.0024(4.00)^{* * *}$ & & \\
\hline$g S L L_{t-1}$ & $0.0035(2.27)^{* *}$ & & \\
\hline$g S F L_{t-1}$ & $0.0090(4.70) * * *$ & & \\
\hline$g S S L L_{t-1}$ & $0.0150(2.61)^{* * *}$ & & \\
\hline$g S S F L_{t-1}$ & $0.0561(2.00)^{* *}$ & & \\
\hline$g U S L L_{t-1}$ & $-0.0241(-2.39)^{* * *}$ & & \\
\hline \multirow[t]{2}{*}{$g U S F L_{t-1}$} & $-0.0450(-3.06)^{* * *}$ & & \\
\hline & The short run results & & \\
\hline \multicolumn{4}{|l|}{$\triangle g G D P_{t}$} \\
\hline$E C T$ & $-0.1241(3.13)^{* * *}$ & & \\
\hline$\triangle g F D I_{t}$ & $0.0010(2.25) * *$ & & \\
\hline$\triangle g O P N_{t}$ & $0.1242(3.31)^{* * *}$ & & \\
\hline$\Delta g R \& D_{t}$ & $0.0038(-4.30)^{* * *}$ & & \\
\hline$\Delta g K_{t-1}$ & $0.0023(4.45)^{* * *}$ & & \\
\hline$\Delta g S L L_{t-1}$ & $0.0058(1.27)$ & & \\
\hline$\Delta g S F L_{t}$ & $0.0130(0.67)$ & & \\
\hline$\triangle g S S L L_{t}$ & $-0.0062(-0.74)$ & & \\
\hline$\Delta g S S F L_{t-1}$ & $-0.0157(-1.46)$ & & \\
\hline$\Delta g U S L L_{t-1}$ & $0.1079(1.80)^{*}$ & & \\
\hline$\triangle g U S F L_{t}$ & $-0.0064(-1.93)^{* *}$ & & \\
\hline Constant & $1.6857(2.86)^{* * *}$ & & \\
\hline Hausman Test & & 2.6 & 0.8651 \\
\hline
\end{tabular}

(Notes) (i) Number in the parenthesis represents the absolute value for $\mathrm{z}$.

(ii) $* * *$ denote statistical significance at the $1 \%$ level,

** denote statistical significance at the $5 \%$ level,

* denote statistical significance at the $10 \%$ level. 


\section{Conclusion}

The results from the study reveal that the benefits of hiring both skilled and semiskilled foreign labours are obtained in the long run, even though their contribution are not significant in the short run. However, unskilled labours, irrespective of whether foreign or local, have a negative effect on economic growth in both the short run and the long run scenarios. The implications of hiring foreign unskilled labours are more important in this context.

The results clearly indicate that skilled and semi-skilled foreign labours must be employed in Malaysia for a longer period in order to gain benefits from their presence. One of the significant issues is how to retain foreign labours for longer periods of time in Malaysia. As far as skilled foreign labours are concerned, most enter the country as a consequence of FDI. Therefore, Malaysia must;

- Sustain FDI in the country long enough by providing suitable investment facilities.

- Offer a more competitive wage structure and working environment.

- Introduce more attractive scheme for their spouse and children.

- Introduce law that is more flexible to ease the entrance to the country.

- Provide enough skilled local labours through training to complement foreign skills and new technologies brought by FDI.

- Provide better infrastructures like health and education for foreign labours' families.

Regarding the unskilled foreign labours who are proven to contribute negatively to the Malaysian economic growth, Malaysia should restrict the entry of such labour. Furthermore, the dependence on this type of labour must be kept low by;

- Encouraging local labours to replace jobs held by unskilled foreign labours by offering a better wage scheme or minimum wage.

- Introducing a better working condition and job security for the unattractive sectors like agricultural and security sectors.

- Introducing a more stringent law to prevent the unskilled foreign labours from entering the country and more effective enforcement of the law, for example, more stern punishment.

- Allowing the unskilled to work only in specified sectors where labour shortages 
exist because of the reluctance of local labours to work in such sectors like agricultural and security sectors.

In conclusion, the reliance on foreign labours cannot be avoided as the Malaysian economy faces labour shortages in certain sectors. The economic activities must be sustained and labour shortages must be resolved. However, the reliance on foreign labours, especially on low skilled foreign labours, must be addressed since such labours adversely affect the economic growth. The Malaysian government must design a stern policy to curb the influx of unskilled foreign labours, while fostering policies to attract skilled foreign labours to encourage brain gain.

Received 2 September 2014, Revised 9 October 2014, Accepted 20 October 2014

\section{References}

Athukorala, P. "The Use of Migrant Remittances in Development: Lessons from The Asian Experience.” Journal of International Development, 4(1992): 511-529.

Azizah Kassim. "Contemporary Labour Migration in Malaysia: An Overview." Paper presented at a seminar on The Media and Labour Migration in Malaysia, Asian Institute for Development Communication (AIDCOM), Kuala Lumpur, October 27-29, 1998a,

Azizah Kassim. "Profile of Foreign Migrant Workers in Malaysia: Towards Compiling Reliable Statistics." Paper presented at a Conference on Migrant Workers and the Malaysian Economy, organized by the Malaysian Institute of Economic Research (MIER) and the Friedrich Naumann Foundation, May 19-20, 1998 b.

Borjas, G. "The Economics of Immigration." Journal of Economic Literature, 32(1994): $1667-1717$.

Central Bank of Malaysia Annual Report, Accessed June 25, 2013.: http://www.bnm. gov.my/files/publication/ar/en/2013/ar2013_en.pdf

Christofides, L.N., Clerides, S., Hadjiyiannis, C. and Michael, M. S. "The Impact of Foreign Workers on Labour Market of Cyprus." Cyprus Economic Policy Review, 
1(2007): 37-49.

Coury, T. and Lahouel, M. “ Economic Growth With Unlimited Supply of Foreign Labor, Theory and Some Evidence from GCC." Working Paper, The Dubai Initiative, Belfer Center for Science International Affairs, Harvard Kennedy School, January, 2011.

Drinkwater, S., Levine, P., Lotti, E. and Pearlman J. “The Immigration Surplus Revisited in a General Equilibrium Model with Endogenous Growth." Journal of Regional Science, 47((2007), 569-601.

Friedberg, R. and Hunt, J. "The Impact of Immigrants on Host Country Wages, Employment and Growth." Journal of Economic Perspectives, 9(1995): 23-44.

Green A.E., Jones P. and Owen D. "Migrant Workers in the East Midlands Labour Market.”, Report for the East Midlands Development Agency, 2007.

Hausman, J. A. "Specification Tests in Econometrics.” Econometrica, 46((1978): 71.

Kanapathy, V. "Managing Cross Boader Labour Mobility in Malaysia: Two Decades of Policy Experiments." Paper presented at PECC_ABAC Conference on Demographic Change and International Labor Mobility in the Asia Pacific R: Implication for Business and Corporation, March 25-26, 2008.

Kurus, B. "Migrant Labour: The Sabah Experience." Asian and Pacific Migration Journal, 7((1998):281-295.

Ministry of Home Affairs Malaysia, Official Documents. Kuala Lumpur: National Publication, 2005.

Ministry of Home Affairs Malaysia, Official Documents. Kuala Lumpur: National Publication, 2011.

Pesaran, M. H., Shin, Y. and Smith, R. "Pooled Mean Group Estimator of Dynamic Heterogeneous Panels." Journal of the American Statistical Association, 94(1999):621634.

Pesaran, M.H. and Im, K.S. and Shin, Y. "Testing for Unit Roots in Heterogeneous Panels." Cambridge Working Papers in Economics 9526. Faculty of Economics, University of Cambridge, 1995.

Pillai, P. "The Impact of the Economic Crisis on Migrant Labour in Malaysia: Policy Implications." Asia and Pacific Migration Journal, 7((1998):255-80. 
Portes, J. and French, S. "The Impact of Free Movement of Workers from Central and Eastern Europe on the UK Labour Market: Early Evidence," Department for Work and Pensions Working Paper 18, 2005, Corporate Document Services, Leeds.

Rahmah Ismail, Nasri Bachtiar, Zulkifly Osman and Zulridah Mohd Noor. "The Role of Foreign Labour on Output Growth, Job Opportunity and Wages in Malaysia Manufacturing Sector.” Jurnal Ekonomi Malaysia, 37(2003):103-128.

Solehah, Abdul Hamid and Gordon Dicks. "Can Malaysia Survive without Foreign Labour?” Working Paper Malaysian Institute of Economic Research (MIER), 1999.

Thangavelu, S. M. "Economic Growth, Welfare and Foreign Workers: Case of Singapore." Paper presented at the International Conference on Trade, Investment and Production Networks in Asia Leverhulme Centre for Research on Globalisation and Economic Policy (GEP), University of Nottingham 15th and 16th February, 2012

Zehadul Karim, AHM, Moha Asri Abdullah and Mohd. Isa Haji Bakar. "Foreign Workers in Malaysia: Issues and Implications.” Kuala Lumpur: Utusan Publications, 1999.

Zimmermann, K. "The European migration problem." Journal of Economic Perspectives, 9((1995): 45-68. 